\section{SOI: 1.1/TAS DOI: 10.15863/TAS International Scientific Journal Theoretical \& Applied Science}

p-ISSN: 2308-4944 (print)

e-ISSN: 2409-0085 (online)

Year: 2015

Issue: 09

Volume: 29

Published: 30.09 .2015

http://T-Science.org

SECTION 31. Economic research, finance, innovation, risk management.

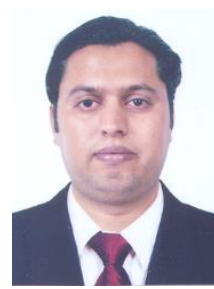

Abdul Rehman

PhD Candidate

College of Economics and Management

Anhui Agricultural University, China abdulrehman@ahau.edu.cn

Luan Jingdong

Dean of College of Economics and Management Anhui Agricultural University, China luanjingdong@ahau.edu.cn

Yuneng Du

Lecturer College of Economics and Management Anhui Agricultural University, China

Duyuneng@ahau.edu.cn

Rafia Khatoon

Master in Business Administration (MBA)

The University of Azad Jammu \& Kashmir

Babar Shahzad

PhD Candidate, School of Agronomy

Anhui Agricultural University, China

\title{
FINANCIAL CRISIS IN PAKISTAN AND ITS IMPACT ON AGRICULTURAL GROWTH
}

Abstract: The main aim of this study is to determine the financial crisis in Pakistan and its impact on the agricultural growth. The Gross Domestic Production GDP of Pakistan growth rate is coming down and also witnessed high fiscal and current-account deficit. The inflation which is an international problem also affected the GDP of Pakistan. The macroeconomic indicators of Pakistan showed very poor performance as Gross Domestic Product GDP growth rate declined from $6.8 \%$ in 2007 to $4.1 \%$ in 2008.

Key words: Financial Crisis, Agricultural Development, Economic Growth, Macroeconomic Stability, International Monetary Fund (IMF).

Language: English

Citation: Rehman A, Jingdong L, Du Y, Khatoon R, Shahzad B (2015) FINANCIAL CRISIS IN PAKISTAN AND ITS IMPACT ON AGRICULTURAL GROWTH. ISJ Theoretical \& Applied Science 09 (29): 52-57.

Soi: http://s-o-i.org/1.1/TAS-09-29-13 Doi: crossef http://dx.doi.org/10.15863/TAS.2015.09.29.13

\section{Introduction}

2008 Global Financial Crisis was the worst crisis since Great Depression of 1930's. It emerged on global of the earth after failure of financial giants like Lehman Brothers, Bears Stearns etc. Crisis was a result of series of problems including the subprime mortgage crisis. Economic Crisis propagated through different channels like financial integration, trade. Global Financial Crisis had serious repercussions. Crisis led to liquidity problems. Poor countries were further pushed into poverty trap. World's total output decreased significantly as real GDP growth rate plunged down to $-1.9 \%$ in 2009 . World's capital markets witnessed decline in stock and bond prices. Policy initiatives were taken all across the globe to mitigate the effects of crisis.

United States and European countries announced bail-out packages worth trillion of dollars. Pakistan also suffered from Financial Crisis as GDP growth rate came down and it further led to economic instability. Pakistan's current account deficit and fiscal deficit touched the figures of $8 \%$ and \& $7 \%$ of GDP respectively. The paper takes into account GDP as a dependent variable and potential independent variables such as trade deficit, current account deficit, fiscal deficit and inflation. GDP has been taken as a measure of macroeconomic stability. The paper further highlights and analyzes the discretionary fiscal policy adopted by the government and tight monetary policy being pursued by the State Bank of Pakistan.

\section{Literature Review of Financial Crisis}

Carmen M. Reinhart (2000) says during the past few years, many countries have suffered severe currency and banking crises, producing a staggering toll on their economies, particularly in emergingmarket countries. In many cases, the banking sector has been in excess of 20 percent of GDP, and output declines in the wake of crisis have been as large as 14 percent. An increasingly popular view blames fixed exchange rates, specifically "soft pegs," for 
these financial meltdowns. Not surprisingly, adherents to that view advise emerging markets to join the ranks of the United States and other industrial countries that have chosen to allow their currency to float freely [8]. At first glance, the world (with the notable exception of Europe) does seem to be marching steadily toward floating exchange-rate arrangements.

According to the International Monetary Fund (IMF), 97 percent of its member countries in 1970 were classified as having a pegged exchange rate; by 1980, that share had declined to 39 percent and in 1999, it was down to only 11 percent. Even in the Asian crisis countries' exchange rates prior to the 1997 crisis would suggest that their exchange rates looked very much like pegs to the U.S. dollar for extended periods of time. In the late 1980s and early 1990s have been the decompositions of capital flows directed to developing countries which accompanied a robust increase in overall flows.

Commercial bank lending, which supported the bulk of the debt rescheduling in early 1980s following Mexico's bank debt moratorium in August 1982, and, to a lesser extent, official flows (i.e. financial aid, concessionary and conditional loans) have given way to a substantial increase in other private inflows, that is to both short-term and longterm portfolio placements and direct investments. According to the IMF, while the total external debt of developing countries increased by almost $40 \%$ to USD 1,600 billion between 1987 and 1994, the external debt owed to non-bank private sources, which was some $14 \%$ of the total at the end of 1987 , had reached almost $27 \%$ by end of 1994 , and is now expected to grow to some $31 \%$ by end of 1996 . Conversely, external bank debt fell from $41 \%$ of the total in 1987 to $28 \%$ over the same period, contracting in absolute terms in the process. This trend is even more pronounced if one concentrates the attention on certain subsets of developing countries.

For instance, developing countries in the Western Hemisphere (i.e., mostly Latin American countries) saw the relative importance of external private non-bank debt increased almost threefold, from about $13 \%$ to $38 \%$ of overall foreign debt, while that of commercial bank debt was halved from $62 \%$ to $31 \%$. The global economic challenges of the 1980s, the colossal debt overhang, wild swings in exchange rates and continue observing imbalances in external payments have presented the IMF with the immense task of devising orderly and effective solutions. And they have focused unprecedented attention on the organization. Thrown suddenly and inadvertently into the epicenter of the world economic crises after the 1973-1974 oil price shocks, the IMF has gradually and erroneously come to be seen as the world's master economic trouble-shooter. A limited-purpose organization, conceived in 1944 to deal with 1930s style exchange and payments problems, the Fund has recently been pushed by circumstances into becoming a superagency in charge of the global debt and development problems of the 1970s and 1980s tasks for which it has neither adequate expertise nor sufficient resources.

Borrowing from the IMF did not initially involve 'conditionality' this was introduced in the 1950 s as the USA continued to fear that it might in effect be required to underwrite the Fund's lending operations. By the time the Bretton Woods system was up and running at the end of the 1950s, when the free convertibility of European currencies was introduced, the IMF had assumed the general role of overseeing, or even managing, the Bretton Woods system. This system involved countries pegging the par values of their currencies, and only altering them in the event of a 'fundamental disequilibrium', where domestic and external policy targets became incompatible at the pegged exchange rate. However, not all currencies were treated equally. The US dollar was made the pivot of the system, with its price being tied to gold.

Countries in economic crisis that urn to the IMF for supporting habit their ability to attract multinational investors, countries weathering a financial crisis attract fewer FDI inflows if they sign IMF agreements . As the debate about international financial reform was going on, the world was in effect forced by expediency to adopt generalized flexible exchange rates in 1973 to try and correct persistent currency misalignment, and encountered an enhanced need for international financial intermediation in the context of the quadrupling in the price of oil in 1974, which created large surplus in the oil exporting countries and large deficits among oil importers. While the Fund responded by creating a temporary oil facility designed to recycle oil revenues from oil producers to countries with oilrelated balance of payments deficits, the task of recycling petrodollars was largely performed by private international banks. Early in the 1980s, and partially in response to a second big increase in oil prices at the end of the 1970s and a change in the dominant economic paradigm, the Fund had retreated from the EFF and had, in effect, phased out low conditionality lending through reforms to the CFF. The emphasis had returned to conventional macroeconomic stabilization based on controlling aggregate demand through fiscal and monetary policy.

In the late 1980s, the Fund offered an institutional response to concern that it was underemphasizing the supply side and the social 
consequences of adjustment. Its rhetoric began to refer more to encouraging economic growth as a 'primary' objective of adjustment programmers and protecting 'vulnerable groups' from the costs of adjustment. Perhaps most notably, the Fund introduced in 1987 the Enhanced Structural Adjustment Facility (ESAF). This was targeted at low income countries and emphasized a broader range of conditionality which, while still including conventional demand-side measures, also included specific supply-side and microeconomic measures. Hamilton (2005) argues that a potential macroeconomic effect of oil price is on the inflation rate as long run inflation rate is governed by monetary policy, and so ultimately it depends on how the central bank responds to oil prices. Nevertheless, LDC debt to foreign bankers is beyond redemption, as the laws of mathematics operate inexorably to accelerate the interest burden beyond even the most optimistic assessment of ability to pay.

\section{Impact on Pakistan GDP}

Global Financial Crisis hampered Pakistan's economic growth to a great extent. Deteriorating foreign exchange reserves position due to Balance of Payment crisis compelled Government of Pakistan to approach IMF for a bail out package. Foreign Direct Investment (FDI) carries a considerable importance in economic growth and as a result of Global
Financial Crisis. FDI came down from $\$ 5410$ million in 2008 to $\$ 3720$ million in 2009. Global Financial Crisis has also widened the Trade Gap in Pakistan as Trade Deficit rose to $12.8 \%$ of GDP in 2008.

Unfortunately, Pakistan was suffering from different problems and thus government was not in a condition to provide a bail-out package. Pakistani government had adopted tight monetary policy to curb the rising inflation and similarly it also went for an expansionary fiscal policy as there is no room for counter cyclical fiscal policy.

Pakistan faces a major challenge of achieving macroeconomic stability and putting economy back on track. Fiscal and Monetary Policy carry a relative importance and thus there is a need to study the effectiveness of both the Fiscal and Monetary Policy in stabilization of Global Financial Crisis.

Global Financial Crisis has brought attention towards many issues. Crisis has revealed that there is a need for reformation. International Monetary Fund needs reformation. Similarly, there is a lot of betterment required in financial system of the World.

\section{Pakistan GDP Last Ten Years (2006-2015)}

The Gross Domestic Production GDP, GDP growth rate and GDP per capita of Pakistan is graphically shown in fig 1, fig 2 and fig 3.

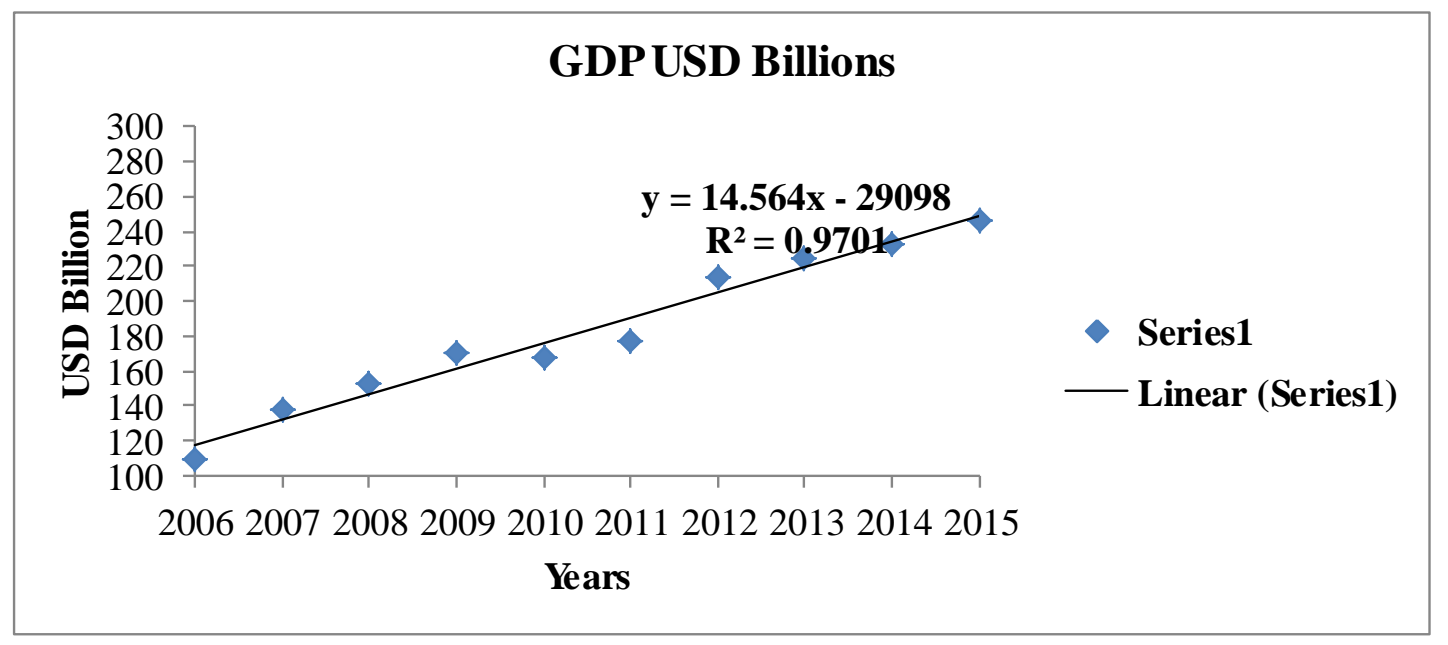

Data source: Pakistan Bureau of Statistics

Figure 1 - GDP USD Billions.

During ten years from 2006 to 2015 fig 1 shows an increase in its total GDP. Overall trend of GDP shows depicts steep value. The minimum value was recorded in 2006 i.e., 109.5 USD Billion and maximum value i.e., 246.88 USD Billion was recorded in 2015 shows an increase of one fold of its original value. 


\begin{tabular}{|c|c|c|c|c|c|c|}
\hline Impact Factor: & $\begin{array}{l}\text { ISRA (India) } \\
\text { ISI (Dubai, UAE } \\
\text { GIF (Australia) } \\
\text { JIF }\end{array}$ & $\begin{array}{l}=1.344 \\
=0.829 \\
=0.356 \\
=1.500\end{array}$ & $\begin{array}{l}\text { SIS (USA) } \\
\text { PИHЦ (Russia) } \\
\text { ESJI (KZ) } \\
\text { SJIF (Morocco) }\end{array}$ & $\begin{array}{l}=0.912 \\
=0.179 \\
=1.042 \\
=2.031\end{array}$ & ICV (Poland) & $=6.630$ \\
\hline
\end{tabular}

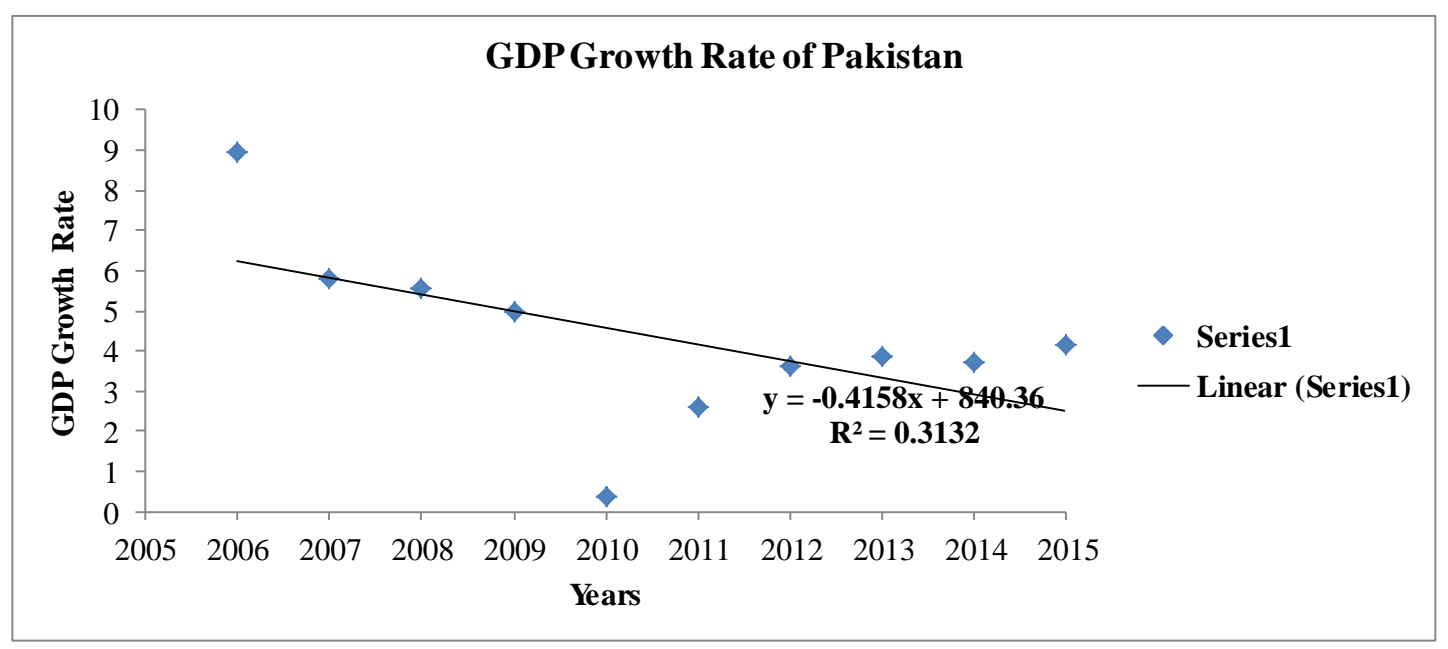

Data source: Pakistan Bureau of Statistics

Figure 2 - GDP Growth Rate of Pakistan.

Overall GDP growth rate shows steep value. The minimum value was recorded in 2006 i.e., 8.96 and maximum value 4.14 was recorded in 2015 and overall value was decreased.

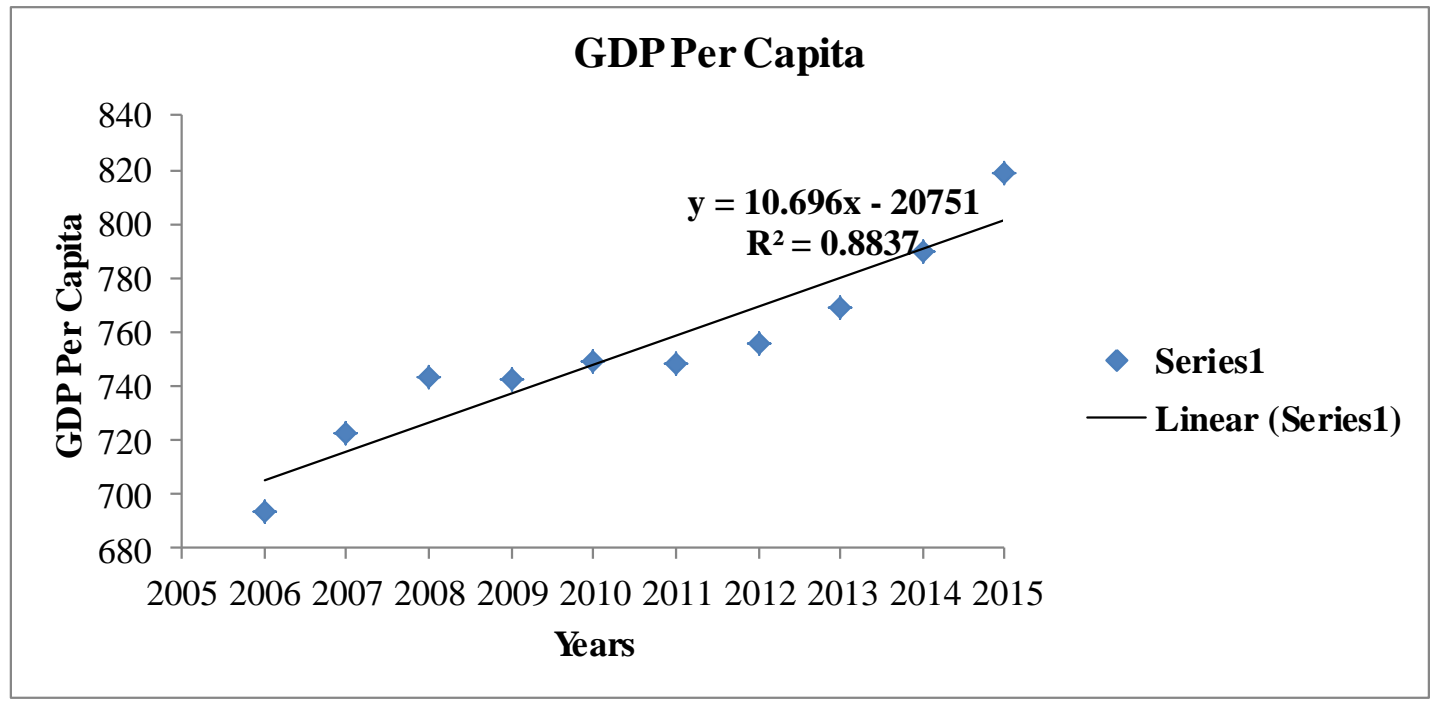

Data source: Pakistan Bureau of Statistics

Figure 3 - GPD Per Capita.

Graph shows an increase in GDP per Capita for first three years and last three years, but there was a stagnant curve between two periods.

\section{Conclusion}

Pakistan's deteriorating macroeconomic conditions after the Global Financial Crisis had resulted in sharp downfall in GDP growth rate. Real GDP growth rate declined significantly in 2008 as it reached to $1.6 \%$ and in 2009 it rose slightly to 3.4
$\%$. Unfortunately, Pakistan was already suffering from macroeconomic instability before the Financial Crisis due to hike in oil prices and depleting foreign exchange reserves. Financial Crisis widened trade gap. Increase in budget and current account deficits and soaring inflation brought further problems for Pakistan's economy.

Under IMF agreement Pakistan has to adopt tight fiscal and monetary policies. IMF programme is 
directed towards restoring macroeconomic stability in Pakistan. State Bank of Pakistan has increased discount rates to curb inflation but it has also hampered economic growth. Private investment is restricted due to increase in discount rates. Public finances remain in a precarious state. Pakistan has no fiscal space and there is less room for counter cyclical fiscal policy. In counter cyclical fiscal policy, taxes are cut and spending is increased during downturns to promote economic recovery and growth. Discretionary fiscal policy cannot be adopted in Pakistan as public debt is high and government is unable to finance the resulting fiscal deficit. Tax evasion is already on peak in Pakistan and as a result Pakistan's tax to GDP ratio is very low.
It can easily be concluded that GDP is one of the measures of macroeconomic stability and regression results have made it clear that Current Account Balance, Trade Deficit and even Inflation had an impact on GDP. Multiple Regression Analysis has depicted that Null Hypothesis should be accepted. Global Financial Crisis had a severe impact on macroeconomic stability of Pakistan. Null Hypothesis that high fiscal deficit decreased GDP growth has not been justified by the regression analysis. Null Hypothesis that widening of trade deficit has caused decline in GDP needs to be accepted as shown by the regression results.

\section{References:}

1. Hon Chu K (2007) Financial crises, liberalization, and government size. Cato J., 27, 37.

2. Latif A, Nazar MS, Shah MZ, Shaikh FM (2011) Global Financial Crisis: Macroeconomic Linkage to Pakistan's Agriculture. Asian Social Science, 7(7), 90-93.

3. Granger CWJ (1986) Developments in the Study of Cointegrated Economic Variables. Oxford Bulletin of Economics and Statistics, affecting the GDP; it is also resulting in higher 48(3): 213-28.

4. Amjad R (2010) Economic and social impact of global financial crisis: implications for macroeconomic and development policies in South Asia. PIDE Monograph Series.

5. Meissner CM, Brodo MD (2006) The Role of Foreign Currency Debt in Financial Crises: 1880-1913 versus 1972-1997. Journal of Banking and Finance, of debt. 30: 3299-3329.

6. Batool I, Imran R, Chani MI, Hunjra AI, Jasra JM (2011) Financial crises and economic growth in Pakistan: a time series analysis. Middle-East Journal of Scientific Research, 9(3), 425-430.

7. Nazir MS, Safdar R, Akram MI (2012) Impact of Global Financial Crisis on Banks' Financial Performance in Pakistan. American Journal of Scientific Research, (78), 101-110.

8. Ahmed V, OlDonoghue C (2010) Global economic crisis and poverty in Pakistan. International Journal of Microsimulation, 3(1), 127-129.
9. Reinhart CM (2000) The mirage of floating exchange rates. American Economic Review, 65-70.

10. Weeks J (2009) 'The impact of the global financial crisis on the economy of Sierra Leone', UNDP Country Study no. 18. United National Development Programme, New York.

11. Goldstein M, Hills CA, Peterson PG (1999) Safeguarding Prosperity in a Global Financial System: The Future International Financial Architecture: Report of an Independent Task Force Sponsored by the Council on Foreign Relations. Peterson Institute.

12. Scattaglia M, Steinherr A (1998) Emerging Market Financing: Potential and Risks Illustrated with a Study of Mexico. Revue economique, 87-102.

13. Amuzegar J (1986) The IMF under fire. Foreign policy, 98-119.

14. Bird G (2001) A suitable case for treatment? Understanding the ongoing debate about the IMF. Third World Quarterly, 22(5), 823-848.

15. Jensen NM (2004) Crisis, Conditions, and Capital The Effect of International Monetary Fund Agreements on Foreign Direct Investment Inflows. Journal of Conflict Resolution, 48(2), 194-210.

16. Chen S, Ravallion M (2009) 'The impact of global financial crisis on the world's poorest', Working Paper, World Bank, Washington D.C..

17. Hamilton JD (2005) Oil and the Macroeconomy. The New Palgrave Dictionary of Economics Palgrave Macmillan, London. Available online at http://www. dictionaryofeconomics. com/dictionary. 


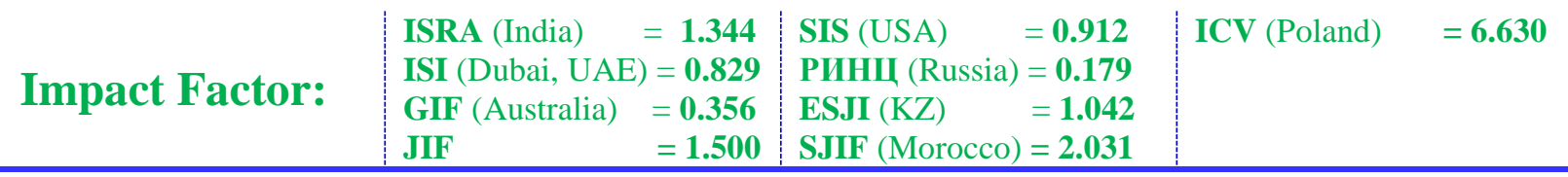

Jimenez-Rodríguez, Rebeca and Marcelo Sanchez, 201-228.

18. (2015) IMF and Pakistan Pakistan Bureau of Statistics.

19. Fryer DW (1987) The political geography of international lending by private banks.
Transactions of the Institute of British Geographers, 413-432.

20. Bourguignon F, Robilliard AS, Robinson S (2003) Representative versus real households in the macroeconomic modelling of inequality. Dial document de travail dt/2003-10. 